УДК 811.161.2'36:001.4

doi: $10.32620 / g c h .2019 .4 .12$

Медведь О. В., Рижккова В. В.

\title{
ДО УТОЧНЕННЯ ПАРАМЕТРІВ ТЕРМІНОЛОГІЧНОЇ СИСТЕМНОСТІ В ПРИКЛАДНОМУ ТЕРМІНОЗНАВСТВІ
}

У статті актуалізовано питання про сутність термінологічної системності в їі практичному аспекті. Систематизовано погляди науковців на рівні системності в термінологї - понятійний, лінгвістичний і логіко-лінгвістичний.

Ключові слова: термінологія, термін, терміносистема.

The peaper is devoted to the study of the terminological systems in practical aspect. The vieur of scientist on the levels of systems in terminology - conceptual, linguistical and logical-linguistical are analized.

Keywords: terminology, term, term system.

Сучасні науковці констатують, що у вітчизняному термінознавстві спостерігається розвиток низки незалежних напрямків дослідження - історичного, теоретичного, прикладного, зіставного (порівняльного), функційного, когнітивного тощо. Проте найчастіше об'єктом уваги стають саме конкретні термінології (терміносистеми), тобто сукупності термінологічних одиниць, окреслені межами певної науки, технічної галузі, сфери практичної людської діяльності. При цьому спеціалісти, визначаючи кількісний і якісний склад обраної для аналізу термінології, достатньо послідовно користуються поняттями «наука», «техніка», а також деякими іншими концептами суспільної практики, а саме «професія», «сфера людських знань», «суспільно-політичне життя».

Мета пропонованого дослідження - уточнити параметри термінологічної системності в межах опису й аналізу конкретної вузькогалузевої термінології.

Системність як одна 3 основних властивостей термінології підкреслюється в багатьох вітчизняних i зарубіжних термінознавчих дослідженнях. Однак аналіз численних робіт у галузі термінознавчої діяльності свідчить, що застосування названого положення під час конкретних досліджень є доволі дискусійним і потребує певних уточнень.

Перший підхід до визначення параметрів терміносистеми в практиці термінознавства усталився як логічний.

Думка, що термін слід розглядати не ізольовано, а як член певної системи, була висловлена в працях Д. Лотте, який, власне, і запропонував поняття системності термінології. Основним обгрунтуванням системного характеру термінології вважається системність відношень терміна-поняття: місце терміна в терміносистемі визначається місцем поняття у відповідній системі понять.

Власне концепт «поняття» посідає центральне місце в логіці, оскільки вся 
система логічних доведень грунтується на ньому. Філософський енциклопедичний словник визначає поняття як «...думку, що відтворює в узагальненій формі предмети та явища дійсності й зв'язки між ними за допомогою фіксації загальних і специфічних ознак, що подаються як властивості предметів та явищ і стосунки між ними» [9, c. 513].

У понятті передусім розрізняють зміст та обсяг. Зміст поняття - це сукупність відтворених у ньому ознак предметів. Обсяг поняття - це сукупність (клас) предметів, кожному з яких властиві ознаки, що стосуються змісту поняття. Відповідно до цього логічного положення в термінознавстві стосовно терміна також говорять про його зміст та обсяг.

Серед понять виділяються надзвичайно широкі категорії: предметів, процесів, властивостей, величин. Відзначимо, що в термінознавстві поділ термінів на понятійні категорії здійснювався переважно на матеріалі технічних терміносистем, що й зумовило набір виділених категорій: категорія предметів, категорія процесів, категорія станів, категорія режимів, категорія наук і галузей, категорія професій та занять [3, с. 9].

Поняттям, що входять до кожної з таких категорій, притаманна певна сукупність ознак. Зокрема для понять категорій предметів найбільш властивими є такі ознаки: форма, розмір, походження, конструкція, призначення, матеріал, хімічний склад, принцип діяльності тощо [1, с. 28]. Зауважимо, що саме логічне положення про понятійні категорії особливо активно застосовується в термінознавчій роботі під час стандартизації термінології.

Поняття не існують ізольовано, їх розглядають у відношеннях 3 іншими поняттями. Це логічне твердження стало підгрунтям для термінознавчого положення про вже згадуваний зв'язок термінів у межах кожної терміносистеми [3, с. 37]. Особливої ваги термінологи надають родо-видовим, або гіперо-гіпонімічним відношенням [5, с. 254], важливість яких полягає в тому, що вони охоплюють понятійну систему в цілому, ієрархіїзуючи їі.

Таким чином, понятійна система складається з понять і зв'язків між ними.

Залежність терміна від системи понять виявляється і в особливій парадигматиці, у специфічному характері поєднання терміна 3 іншими термінами в межах кожної терміносистеми.

Другий, протилежний, підхід був названий у науковій літературі «виокремленням терміносистем за власне лінгвістичними чинниками» [8, с. 173]. Як правило, за такого підходу дослідники розмежовують поняття термінополя i терміносистеми: «На відміну від поля - предметної галузі, з якою співвідноситься термін як спеціальне поняття, система для терміна - у першу чергу лінгвістична впорядкованість спеціальних слів, що обслуговують певне термінологічне поле» [7, c. 116].

За такого підходу серед науковців немає одностайності у визначенні системних параметрів терміносистеми. Зокрема автори підручника «Українське термінознавство» називають найголовнішими системоутворювальними параметрами лексико-парадигматичні явища синонімії, антонімії, гіперо-гіпонімії [5, с. 180-194]. 
В. Письмиченко, досліджуючи будівельну терміносистему української та англійської мов, зазначає, що «...системний характер термінології значною мірою визначається наявністю в них певних лексико-тематичних груп» $[6$, с. 83]. В. Даниленко, аналізуючи лінгвістичні системоутворювальні параметри, підкреслює, що мовознавчий критерій у цьому питанні складається з кількох пунктів: частиномовна приналежність термінів (морфологічний рівень), явища синонімії (лексикосемантичний рівень), терміноутворення, термінотворча варіантність (словотворчий рівень), особливості функціонування граматичних категорій (граматичний рівень) [1, c. 73].

Прихильники третього підходу до визначення сутності терміносистеми синтезують два попередні і стверджують, що системність у термінології має подвійний логіко-лінгвістичний характер [5, с. 147; 7, с. 118]. Ми схильні вважати, що саме цей підхід дозволяє, по-перше, врахувати подвійну сутність терміна як слова й поняття i, по-друге, пояснити поширену в термінознавчій літературі думку, що термінології як окремому прошарку лексики притаманна більш виражена системність, аніж іншим лексичним групам.

Отже, є всі підстави вважати, що розуміння системності терміносистеми як явища подвійного логіко-лінгвістичного плану вимагає чіткішого розмежування логічних і лінгвістичних чинників їі формування.

На логіко-понятійному рівні спираємося на те, що в логіці понятійну систему розглядають як сукупність понять і зв'язків між ними, тобто на зазначеному рівні організації терміносистеми можемо визначити два основні системні параметри:

1) наявність певних понятійних категорій - найширших за значенням понять;

2) понятійні зв'язки між термінами на внутрішньокатегоріальному й міжкатегоріальному рівні.

На понятійно-словесному рівні, тобто на тому рівні, де термін функціонує як слово, що має відповідне значення, виділяємо такі системоформувальні параметри: синонімія й антонімія термінів.

На власне словесному рівні визначаємо такі системоутворювальні параметри:

1) структурну типологію термінів;

2) явище варіантності;

3) термінотворчі зв'язки термінів.

Зазначені параметри видаються нам достатніми для комплексного опису сучасного стану конкретної вузькогалузевої термінології (терміносистеми).

\section{Література:}

1. Волкова И. Н. Стандартизация научно-технической терминологии. М. : Наука, 1984. 206 с.

2. Даниленко В. П. Русская терминология: Опыт лингвистического описания. М.: Наука, 1977. $246 \mathrm{c}$.

3. Канделаки Т. Л. Семантика и мотивированность терминов. М. : Наука, 1977. 168 с.

4. Лотте Д. С. Основы построения научно-технической терминологии. Вопросы теории и методики. М. : Изд. АН СССР, 1961. 158 с. 
5. Панько Т. І., Кочан І. М., Мацюк Г. П. Українське термінознавство : підручник. Львів : Світ, 1994. $216 \mathrm{c}$.

6. Письмиченко А. Формування індустріально-будівельної термінології української, російської та англійської мов. Матеріали II Всеукраїнської наукової конферениї «Украӥнська термінологія $i$ сучасність». Київ, 1997. С. 82-85.

7. Суперанская А. В., Подольская Н. В., Васильева Н. В. Общая терминология: Вопросы теории. М. : Наука, 1989. 246 c.

8. Циткина Ф. А. Системный анализ в сопоставительном терминоведении. Изв. АН СССР. Сер. лит. и яз. 1987. Т. 46. № 6. С. 557-563.

9. Философский энциклопедический словарь / Гл. редакция: Л. Ф. Ильичев, П. Н. Федосеев, С. М. Ковалев, В. Г. Панов. М. : Сов. Энциклопедия, 1983. 840 с.

\section{References:}

1. Volkova, I. N. (1984), Standartizatsiya nauchno-tekhnicheskoy terminologyi [Standardization of scientific and technical terminology], Nauka, Moscow, 206 p.

2. Danilenko, V. P. (1977), Russkaya terminologiya: Opyt lingvisticheskogo opisaniya [Russian terminology: The experience of linguistic description], Nauka, Moscow, $246 \mathrm{p}$.

3. Kandelaki, T. L. (1977), Semantika i motivirovannost' terminov [Semantics and motivation of terms], Nauka, Moscow, $168 \mathrm{p}$.

4. Lotte, D. S. (1961), Osnovy postroyeniya nauchno-tekhnicheskoy terminologii. Voprosy teorii $i$ metodiki [Fundamentals of the construction of scientific and technical terminology. Questions of theory and methodology], Izd. AN SSSR, Moscow, 158 p.

5. Pan'ko, T. I., Kochan, I. M. and Matsyuk, H. P. (1994), Ukrayins'ke terminoznavstvo [Ukrainian terminology], Svit, L'viv, 216 p.

6. Pys'mychenko, A. (1997), Formuvannya industrial'no-budivel'noyi terminolohiyi ukrayins'koyi, rosiys'koyi ta anhliys'koyi mov [Formation of industrial-construction terminology of Ukrainian, Russian and English], Proceedings of the Second All-Ukrainian Scientific Conference «Ukrainian Terminology and Modernity», Kyiv, pp. 82-85.

7. Superanskaya A. V., Podol'skaya N. V. and Vasil'yeva N. V. (1989), Obshchaya terminologiya: Voprosy teorii [General terminology: Questions of theory], Nauka, Moscow, $246 \mathrm{p}$.

8. Tsitkina, F. A. (1987), Sistemnyy analiz v sopostavitel'nom terminovedenii [System analysis in comparative terminology], Izv. USSR Academy of Sciences. Ser. lit. and language, Vol. 46, No. 6, pp. 557563.

9. Filosofskiy entsiklopedicheskiy slovar' (1983) [Philosophical Encyclopedic Dictionary), Ch. Edition Ilyichev, L. F., Fedoseev, P. N., Kovalev, S. M. and Panov, V. G., Sov. Encyclopedia, Moscow, 840 p.

\section{Olena Medved, Viktoria Ryzhkova}

\section{TO SPECIFY PARAMETERS OF TERMINOLOGICAL SYSTEM IN APPLIED TERMINOLOGY}

The article deals with the logical-linguistic parameters of a narrow-branch term system.

The main rationale for the systemic nature of terminology is the system of termconcept relationships: the place of the term in the term-system is determined by the place of the concept in the corresponding system of concepts. In logic, the conceptual system is considered as a set of concepts and relations between them, that is, at the specified level of 
organization of the term system we can define two basic system parameters: the presence of certain conceptual categories - the broadest in terms of meaning; conceptual connections between terms at the intra-categorical and inter-categorical levels.

On the verbal level, it is necessary to distinguish the following system-forming parameters: the structural typology of terms and their term-forming relationships.

Understanding the systemic system of the term system as a phenomenon of the dual logico-linguistic plan requires a clearer identification of the relationship between the logical and linguistic factors of its formation.

Keywords: terminology, term, term system.

\section{Олена Медведь, Вікторія Рижкова}

\section{ДО УТОЧНЕННЯ ПАРАМЕТРІВ ТЕРМІНОЛОГІЧНОЇ СИСТЕМНОСТІ В ПРИКЛАДНОМУ ТЕРМІНОЗНАВСТВІ}

У статті розглянуто логіко-лінгвістичні параметри вузькогалузевої терміносистеми.

Основним обгрунтуванням системного характеру термінології вважають системність відношень терміна-поняття: місце терміна в терміносистемі визначається місцем поняття у відповідній системі понять. У логіці понятійну систему розглядають як сукупність понять і зв'язків між ними, тобто на зазначеному рівні організації терміносистеми можна визначити два основні системні параметри: наявність певних понятійних категорій - найширших за значенням понять; понятійні зв'язки між термінами на внутрішньокатегоріальному й міжкатегоріальному рівні.

На власне словесному рівні варто виділяти такі системоутворювальні параметри: структурну типологію термінів і їхні термінотворчі зв'язки.

Розуміння системності терміносистеми як явища подвійного логіколінгвістичного плану вимагає чіткішого виявлення взаємозв'язку логічних i лінгвістичних чинників іiі формування.

Ключові слова: термінологія, термін, терміносистема.

Medved Olena - Ph.D. in Philology, Associate Professor, Associate Professor of the Department of Documentation and Ukrainian Language Faculty of Humanities of the National Aerospace University «Kharkiv Aviation Institute».

Медведь Олена - кандидат філологічних наук, доцент, доцент кафедри документознавства та української мови гуманітарного факультету Національного аерокосмічного університету ім. М. Є. Жуковського «Харківський авіаційний інститут».

e-mail: elenamdvd@gmai.com

Ryzhkova Viktoria - Ph.D. in Philology, Associate Professor, Head of Departament Applied Linguistics Faculty of Humanities of the National Aerospace University «Kharkiv 
Aviation Institute».

Рижкова Вікторія - кандидат філологічних наук, доцент, завідувач кафедри прикладної лінгвістики гуманітарного факультету Національного аерокосмічного університету ім. М. Є. Жуковського «Харківський авіаційний інститут».

Надійшла до редакції 18.11.2019. Розглянута на редколегії 19.11.2019.

\section{Рецензенти:}

Доктор філософських наук, професор, декан гуманітарного факультету Національного аерокосмічного університету ім. М. Є. Жуковського «Харківський авіаційний інститут» Копилов В. О.

Кандидат юридичних наук, доцент, доцент кафедри права гуманітарного факультету Національного аерокосмічного університету ім. М. С. Жуковського «Харківський авіаційний інститут» Гордеюк А. О. 